Central Washington University

ScholarWorks@CWU

Library Scholarship

James E. Brooks Library

2007

\title{
Information technologies and civic engagement: Perspectives from librarianship and planning
}

Aimée C. Quinn

Central WashingtonUniversity, aimee.quinn@cwu.edu

Laxmi Ramasubramanian

Follow this and additional works at: https: / digitalcommons.cwu.edu/libraryfac

Part of the Infrastructure Commons, Library and Information Science Commons, Other Public Affairs, Public Policy and Public Administration Commons, and the Policy Design, Analysis, and Evaluation Commons

\section{Recommended Citation}

Quinn, Aimée C. and Ramasubramanian, Laxmi, "Information technologies and civic engagement: Perspectives from librarianship and planning" (2007). Library Scholarship. 67.

https://digitalcommons.cwu.edu/libraryfac/67

This Article is brought to you for free and open access by the James E. Brooks Library at ScholarWorks@CWU. It has been accepted for inclusion in Library Scholarship by an authorized administrator of ScholarWorks@CWU. For more information, please contact pingfu@cwu.edu. 


\title{
Information technologies and civic engagement: Perspectives from librarianship and planning
}

\author{
Aimée C. Quinn ${ }^{\mathrm{a}, *}$, Laxmi Ramasubramanian ${ }^{\mathrm{b}}$ \\ a Documents, Maps, and Microforms Department, Richard J. Daley Library, University of Illinois at Chicago, \\ $801 \mathrm{~S}$. Morgan, m/c 234, Chicago, IL 60607-7041, USA \\ b Department of Urban Affairs and Planning, Hunter College, City University of New York, \\ 1616A Hunter West, 695 Park Avenue, New York, NY 10021, USA
}

Available online 5 January 2007

\begin{abstract}
Urban planning and librarianship are parallel fields in many ways. Both have theoretical and practical underpinnings driving each discipline; are interdisciplinary in focus; and both professions gather and disseminate information to stakeholders. Essential to the success of each discipline is an engaged user population. The authors use a case study from the Village of Oak Park to examine and reflect upon the effect of the Internet and other technologies in the public's ability to participate in an open planning process. The Village of Oak Park is known for its architectural heritage and outspoken community. Within its 4.5 square miles live a diverse population of approximately 52,000 people from different cultures, races, ethnicities, professions, lifestyles, religions, ages, and incomes where a majority of the population have some advanced education and over $80 \%$ of the households report home Internet use. How does a community like the Village of Oak Park engage in the planning process? What role does information play in this process? Can modern Information Technologies facilitate civic engagement? These questions are examined during a year-long case study conducted by the University of Illinois at Chicago (UIC) in cooperation with the Village of Oak Park (VOP). Specifically, the investigators examined how information is gathered and used in the planning process and how the introduction of Information Technology (IT) tools influenced public participation and introduced many citizens to e-government through the planning process. The use of these tools is compared to the traditional planning process. Data from the project is presented to demonstrate a
\end{abstract}

\footnotetext{
* Corresponding author.

E-mail addresses: aquinn@uic.edu (A.C. Quinn), laxmi@hunter.cuny.edu (L. Ramasubramanian).
} 
different kind of role librarians play in the research process. Last, the authors discuss the role of privacy in the gathering and sharing of information with the reliability of that information and the impact of privacy on the public planning process.

(C) 2006 Elsevier Inc. All rights reserved.

\section{Introduction}

To understand political power right, and derive it from its original, we must consider what state all men are naturally in, and that is a state of perfect freedom to order their actions and dispose of their possessions, and persons as they think fit, within the bounds of the law of nature, without asking leave or depending upon the will of any other man-John Locke (1980).

Librarianship and planning are professions imbued in the use and understanding of the political world. Both librarians and planners find, collect, and disseminate information, yet planners do not archive or provide permanent access to information, a fundamental precept of librarianship. Also, both professions have been impacted by the development of e-government as an information tool. E-government is defined by the E-Government Act of 2002 as:

\footnotetext{
'electronic Government' means the use by the Government of Web-based Internet applications and other information technologies, combined with processes that implement these technologies, to- '(A) enhance the access to and delivery of Government information and services to the public, other agencies, and other Government entities; or (B) bring about improvements in Government operations that may include effectiveness, efficiency, service quality, or transformation.'
}

While the planning literature avoids rigorous reflection or comprehensive analyses of what information or processes are affected by IT, a literature search revealed that new software products were developed to streamline the planning process much the same way as libraries were using IT to streamline their processes. Some of these advances include better use of wireless technology in the field (Mayer, 2006), development of Geographic Information Systems (GIS), and Public Participation Programs (PPP) to allow greater ease in civic engagement (Shiode, 2000). These new technologies drive both librarianship and planning to find new ways to make information accessible to their clients. As such, both professions use information as the means to link to e-government through their advocacy mission in which each profession serves two masters: government officials and the community at large. A fundamental precept to both professions is the need to use and disseminate information to the citizens to enhance community participation in decision making. Librarians understand and facilitate the information life cycle: how information is created, distributed, used, and archived. Planners have a different role in understanding this life cycle by creating and using information in order to clarify and define data for further distribution amongst stakeholders which fosters a better understanding of a project goals.

Planners are political entities. In the context of land use planning, they look at space, place, and human behavior gather and study data in order to recommend actions for the present and future administrations to help alleviate congestion and chaos. At the end of a project, good planning creates a collective community memory of possibilities, opportunities, and constraints 
to inform future generations, yet it is the role of the librarian to insure public access to information in perpetuity beyond memory whereas the role of the planner changes back to information provider. Once planners complete their project, their need for information changes as they move on to the next venture.

The history and theory behind planning is very similar to librarianship. Myers and Banerjee (2005) argue that both professions have split supporters: theorists and practitioners (2005). Planners tend to be people who love to organize data but differ from librarians in that they use their organizational skills to shape space while librarians fill space. Planning is a service industry dependent upon the generation, transmission, and consumption of information. Librarianship is also a service industry dependent upon the generation, transmission, consumption, transformation of information into a new product, and preservation of both the original data and the newly created information.

An unique opportunity arose for a research librarian to study how the information life cycle evolves from project inception to project completion. Specifically, studied were how the planning faculty and graduate students locate, use, and disseminate information and how the recipients of that information were influenced by Information Technologies (IT). Additionally, a knowledge management system was developed for the client to better manage their information. Like many local governments, information about the history and development of the community is found at the local library, neighborhood associations, business groups, historical societies, the village hall, village officials offices, and in some residents homes. The use of IT in the information life cycle proved that e-government made it easier in many ways to track decisions and assess community involvement. It also showed that while the 21 st century is here, most small towns are not prepared to implement e-government fully.

\section{Role of the librarian}

Traditionally, a librarian is on the receiving end of a project. In a planning project, the final, published report is frequently deposited with the local library. As mentioned earlier, for this project a research librarian was invited as part of the faculty team to study how the planning process is shaped by information and in turn, the process shapes civic engagement. The common denominator is information: both the acquisition and dissemination. In order for any stakeholder (citizen, village staff or official, UIC team member, or business owner) to be truly engaged in the process, the flow of information must be unfettered. Introducing basic rules of organization, cataloging, and classification at the beginning of the project maintained transparency between all three parties participating. Having a librarian on the project insured the unambiguous flow of information as well as kept both the village team and the UIC team focused on the larger picture: the citizens. Also, the librarian incorporated methods to provide permanent public access to this information (Hoch et al., 2003).

The librarian as researcher is not a new idea but this role is usually relegated to an in-depth reference interview for the principal investigator or their assistant rather than as an equal participant in the field. Smith (1996) hints at the absence of the librarian as researcher but 
instead focuses on the information professional as expert in citation analysis and literature searching. Specifically, Smith argues:

The implications of this technique on librarians working with interdisciplinary research teams are obvious. Continuous
sweeps of the literature to identify newly published studies must be performed. Being alert to new databases,
vocabulary changes in existing databases, new journals in the field, and the publication of dissertations or monographs
on the area of study are just some of the other sources of studies that must be continuously investigated.

Whereas Dr. Stanley Chodorow (1996) sees the librarian as scholar in the future. His vision hearkens toward the role of the librarian in this project.

Today, in the 2090s, no individual scholar or research group can work without a librarian as a collaborator. Library science is now a track of the advanced degree in every discipline. It is a track taken by people very much like those who once migrated from academic fields into librarianship, but the name librarian now designates not so much a separate profession as a type of scholar. While every scholar and scientist learns how to use information in the creation of new ideas and new information and while each masters a very substantial body of information, the librarian-scholar or scientist is the disciplinary information specialist. [The librarian] is the eyes and ears of the research community, constantly surveying and mapping the information universe for colleagues. Librarians are the ones who know how to find and use the most up-to-date version of scholarly resources, how long these resources are likely to maintain their current shape and content, and how the process of change works ... the corps of librarians ... live in departments and research laboratories and have absorbed many of the duties that used to be performed by computer consultants as well as reference librarians. Their names are to be found among the authors of most publications.

As mentioned above, the librarian served as the project manager and co-director. This position allowed the librarian to shape how information is approached as well as educate team members in the principles of bibliographic control. Furthermore, the graduate research assistants were provided in-depth instruction in evaluating Web resources, literature searching, technical writing, and re-introducing the basic principles of grammar! Through their work with the librarian, the research assistants worked directly with the citizens to create an innovative, transparent process for public participation.

In preparation for the project, the librarian outlined what information needed to be gathered: maps, budgets, marketing reports, crime statistics, economic profiles of the two neighborhoods, previous planning documents for both business districts plus the village, etc. Much of the information used was primarily government publications but the local federal depository library in Oak Park did not have all the reports required. Fortunately, UIC Library is a large federal depository with a significant collection of urban documents so the background information was easily accessible. Some of the current statistics needed were on village staff computers or in their office files. Additionally, staff at the Oak ParkRiver Forest Historical Society and the local newspapers were able to fill in gaps in historical documents. Having to go to personal files, multiple collections, neighborhood organizational records, in addition to the libraries, demonstrated the need for a central knowledge management system.

\section{Information analysis and E-government}

In thinking about the role of information dissemination, government services, information technology, and e-government led the team to conclude that the focus of the project should 
be centered around the citizen. Who is a citizen? Should people who are not citizens have equal access to government information as the citizenry? Should immigrant status play any role in determining who can get what information and when? Does cost bear any significant role in determining what depth of information is available to whom. By what rules and regulations do local government determines who can participate in government? Those living in the community? What about those citizens who work in the community? Does owning property or businesses in the community automatically make one a stakeholder in community decisions? What role, if any, should people who spend money in the community have compared with the taxpayers? What is the perception versus conception of egovernment? What role does the media play in the portrayal and influence of the decision makers?

To answer any of the above questions, the authors determined the best course of action was to identify the data and information needed for the classes to begin their work. As mentioned above, the information was scattered across the village. One important note is that the Village Code does not define "public record" or what constitutes "official information." Instead, the Illinois Compiled Statutes, Municipal Adoption of Codes and Records Act (50 ILCS 220/1) offers the following definition in section 1 (c) and 1 (d):

\begin{abstract}
(c) 'Public record' means any municipal, state, or federal statute, rule, or regulation adopted prior to the exercise by any municipality of the authority to incorporate by reference herein granted; provided, however, that this definition shall not include the municipal ordinances, rules or regulations of any municipality except those of the municipality which is exercising the right to incorporate by reference, nor shall this definition include the state laws, rules, or regulations of any state other than the State of Illinois; (d) 'Published' means printed, lithographed, multigraphed, mimeographed, or otherwise reproduced.
\end{abstract}

(Source: Laws, 1961, p. 1369)

By using the State of Illinois' definition, the village abdicates any responsibility for its own dissemination practices thus calling into question the need for public record. In fact, one of the most frustrating parts of the project was simply trying to get the correct information to the correct people in order to make public participation truly democratic.

Another challenge to the participation is the ability to get public feedback on draft language. Currently, the village does not have the capacity to obtain widespread input on draft information products. The village Web site is for approved, official documents so it is not realistic to include draft forms of future policies. A partnership Web space would allow the public to participate in a variety of tasks and provide the village with important feedback, but at present, the village has no plans about developing such a site.

Last, the codification of a more useful definition to encompass all non-classified information including digital or electronic data produced by taxpayer expense would ease tensions regarding the management of information. This codification would necessarily require enforcement mechanisms to better manage and control information in-put and out-put including electronic mail. These few steps would begin the discussion to answer the questions raised above. The village's own mechanisms for informing their public (Web site, newsletter, TV-station) do not penetrate the community as well as they should, but a dialogue has begun to address these issues. 


\section{The UIC Oak Park Project in a nutshell}

During the spring semester 2002, faculty from the College of Urban Planning and Public Affairs (CUPPA) UIC began a dialogue with the Village of Oak Park (VOP) regarding strategies to effectively incorporate a practical experience for graduate students at UIC and offer the village the experience and skills of the faculty. As a result of this dialogue, UIC contracted with the village to design an inclusive planning process for Oak Park citizens, employees, employers, and officials to study and improve existing business districts. Two main goals emerged: (1) to develop a set of analytical and visual tools to facilitate the process and (2) to develop a vision for the character of two business districts as a model for future development. UIC developed a written proposal that led to a contract between the village and the University signed by the end of the Summer 2002. A team of faculty within CUPPA and the University Library was assembled along with a core group of research assistants comprised of first year graduate students within the urban planning program. These six faculty and seven graduate students became the UIC team while the village assembled key staff for their team.

Additionally, two studio courses were taught in the Fall 2002; one course covered the design features of the two districts while the other course focused on developing IT tools to better engage the community. A series of public meetings were held to engage the public while keeping all parties informed. In conjunction, a public Web site was created to mount the ideas and designs from the classes as well as provide a space for the public to e-mail questions and comments.

During the year-long case study, the librarian was invited to examine how information was being gathered and used as well as to develop a better method of knowledge management for the village. The co-directors oversaw the day-to-day activities including coordinating the activities of all 45 participating students in addition to the long-term strategy to produce a product. While the initial reaction about the project was mixed, this co-directorship built in redundancy that proved necessary the complex operation.

One of the earliest decisions reached in the project was for every citizen to be treated equal to every other citizen - in other words, nobody's opinion counted more than any other regardless of where it came from. Race, income, gender, age, etc., did not factor in any of the decisions for the project.

Another key decision was to allow everyone the opportunity to comment as often as desired. Again, each comment was treated on par with every other comment. Personal information was not collected or used to sway decision makers. The only information kept was what was selfdisclosed; identification was requested if they were commenting as a resident, a business/ property owner, or other. To insure privacy, only the project manager had access to the personal information (e-mail addresses, phone numbers) from those citizen comments who provided personal information. The QRC (Lagace \& McClennan, 1998) software was one successful IT tool used in the project. It insured privacy while allowing comments and questions to be addressed and recorded.

One challenge was the desire by the client to have IT drive the project while the citizens wanted IT to enhance traditional public participation. Although the citizenry of VOP is highly educated and Internet savvy, they clearly preferred the tried and true method of traditional 
participation in lieu of using IT. Even the village staff were not interested in allowing the IT tools to replace traditional work methods. The resistance to using IT to simplify the process was impressive and unexpected but that is part of the tradition of public participation in the Village of Oak Park (Joanne Trapani, President, Board of Trustees, Village of Oak Park, personal communication September 6, 2003).

A work plan was developed dividing the project into three phases (see Appendix for project time line). Each phase was roughly outlined along the academic calendar thus Phase I ran through the fall semester, Phase II ran through the spring semester, and the final phase ran until the beginning of the next fall semester. Within the work plan, specific objectives were outlined and tasks were assigned to each research assistant. A regular meeting time was established for both the UIC team as well as for the VOP team to insure open communication between all parties. Establishing a mechanism for all parties to be heard was one of the most delicate features of the project, but at the same time, one of the most rewarding. Because so many people were involved from both UIC and the village, normal communication patterns were enhanced by IT. The public was kept informed of the project both by traditional open meetings and media alerts as well as through a public Web site that allowed for public comments. The project received a total of 52 e-mail comments about the Project either through the Web site or through direct e-mail. The majority of the comments were positive and thoughtful.

Through the course of the project, five evening community meetings were held where 162 citizens participated. Also, the studio courses involved citizens on a more personal level leading to the creation of a stakeholder group of 30 citizens including residents, business owners, property owners, and commissioners. Throughout the final phase of the project, the stakeholders represented the community at large in refining the designs and visions of the UIC team.

Although the main purpose of the project was to involve the community in a new way using IT to enhance participation, another goal was developing a planning process for the village to use in the future. Through trial and error, the UIC team created an open process involving citizens at all levels of planning from the creation of a vision to the execution of the design elements. This process took an extraordinary amount of time from all parties involved.

From this experience we learned a great deal about civic engagement and community memory. The sections below describe the project and outcomes in more detail.

\section{Public participation and planning}

What is planning? Alexander (1992) proposes an integrated definition of planning that incorporates its complexities.

\footnotetext{
Planning is the deliberate social or organizational activity of developing an optimal strategy of future action to achieve a desired set of goals, for solving novel problems in complex contexts, and attended by the power and intention to commit resources and to act as necessary to implement the chosen strategy.
}

Friedmann (1987) further theorizes public participation as a fundamental precept for planning. By providing opportunities for the public to share their needs and hopes for their 
community, planners are better able to build consensus and bring conflicting communities together around issues rather than around politics. As with any interdisciplinary field, current planning models and frameworks are drawn from many different intellectual traditions. The choice of intellectual tradition defines and influences many aspects of the planning process and the role of the planner. Although many planning traditions call for some form of citizen involvement in the planning process, the nature and scope of that involvement is highly variable. Some planners believe that civic engagement helps build consensus and bring conflicting communities together around specific issues. These planners are also likely to believe in the benefits of the process itself. Others believe that citizen participation is a necessary evil; a political strategy to overcome anticipated community opposition to unpopular planning decisions. Regardless of the reasons for allowing the public to participate, it is fundamentally a difficult proposition. "Involving the public is both bane and boon for planning. Public participation costs time and attention; to the extent that it introduces political and interpersonal complexities into decisions; it compromises planners' autonomy and efficiency" (Carp, 2004). Although many participatory planning processes aspire to create participatory democracy (direct citizen participation), the more established form of citizen participation is an exercise of representative democracy where a group of stakeholders representing different interest groups works with professional planners to shape plans. The UIC Oak Park Project is an innovative partnership between an urban university and an urban community. Citizen activism is probably at the cornerstone of Oak Park's modern identity. Residents in the village have always been outspoken about issues that mattered to them.

The village's 1990 Comprehensive Plan consciously recognizes and emphasizes citizen participation as one of the critical elements of Oak Park's commitment to improve the quality of life for its citizens by seeking to maintain "a high and representative level of citizen involvement in village affairs" (VOP, 1990). In fact, this plan was developed with a committed and engaged community, stakeholder group.

Citizen participation is a complex phenomenon-everyone participates in public life in their own way and at their own comfort level. It is not an overstatement to suggest that every citizen in Oak Park probably has their own unique understanding about how citizen participation in public decision making should be conceptualized and managed. To some, civic engagement is merely an empirical accounting of how many people participated in the making of a particular decision. To many others including members of the UIC team, citizen participation is an overarching philosophy that is essentially at the heart of planning and defines how planning should be done.

In this project, the UIC team sought to develop products (character plans) through an innovative participatory planning process that complements traditional methods of citizen participation by using a range of computer-mediated communication technologies (IT tools). From the village's perspective, the project was intended to provide the village with a set of tools and processes that could be used to develop additional business district plans, with a set of recommendations for the two prototype business districts. The project was intended to allow the village to experience public participation at a higher level through the use of technology and with the additional benefit of student person-hours devoted to 
recording data, opinions, and comments and organizing this information for dissemination in a timely manner.

As professional planners and as Oak Park residents, the authors were quite familiar with the traditional planning processes and various opportunities that were available for citizen input. However, we also recognized that the process of citizen participation, particularly in plan making, was reactive rather than proactive. Typically, a proposal or project would be announced and then citizens would rally for or against it. This set up an adversarial model. For example, proposed changes in density for the surrounding residential area pitted business leaders against the residents. For the business leaders, increased density means a more stable economic base. For the residents, higher density means more traffic, more noise, less green space, and possible change in the character of the neighborhood. UIC worked with all stakeholders to create a compromise plan.

Our philosophy through this project has been to remind everyone - citizens, village staff, and elected board members - that planning is essentially a civic activity and is fundamentally a community endeavor. It is not merely a matter of win or lose, it is about all of us working collectively to create a better place for ourselves and for future generations. We also recognized that citizen participation, when formalized and institutionalized into the decision-making process tends to become bureaucratic and formulaic. One of our goals through this process was to re-energize the processes of civic participation to encourage those residents who typically were unlikely to participate in these planning processes to come forward and volunteer to get involved. We believed that by creating new opportunities for civic engagement, we would create a new energy among the citizenry. In the pivotal book, Bowling Alone, Putnam challenges his readers to "Let us find ways to ensure that by 2010 many more Americans will participate in the public life of our communities - running for office, attending public meetings, serving on committees, campaigning in elections, and even voting". The authors here argue for public participation in the planning process is fundamental for the success of democracy as challenged by Putnam (2000).

Although the planning process focused on the re-development of two specific retail business corridors, the authors believed that residents from around the village should be able to voice their opinions and offer their feedback about the planned development and redevelopment in this area. Technology was seen as a way to make this possible.

\section{Additional points}

- Nationally, participation is on the decline.

- People who participate are older, more educated, and are typically white.

- People are busy - they do not have time to participate.

- Computer-mediated tools were seen as a way to engage folks who were too busy to come to meetings but still cared.

- People are tired - there are so many public meetings in Oak Park.

- A successful ballot referendum on open planning was initiated during the Project. 


\section{Doing participatory planning; establishing communication channels}

Simply put, we talked up the project! Different members of the UIC team talked to different groups. As residents, it was relatively easy for us to talk about the project at different community settings - backyard barbecues, at the gym, at the store, and on e-mail lists. It is important to observe that we talked to anyone who wanted to talk to us rather than working with established community groups or prominent individuals within the community. The project Web site was designed to evolve as the project evolved. This Web site was widely publicized using bookmarks distributed at community events and placed in the local library and bookstores. Newspaper articles appeared soon after. Following the old adage that any publicity is good publicity, we did not wince when the first barbs of criticism appeared almost as soon as we launched the project.

\section{Community-wide public meetings}

After the initial flurry of publicity, the first community meeting was held on September 18th, 2002. About 80 residents attended this first meeting. Some were simply curious and many were anxious about what we were planning to do to their neighborhood. We introduced the team, the project, and the process we would use during the year-long project. This meeting was one of the best opportunities for the public to express their sincere visions and concerns for the future.

We continued to have these open community-wide meetings in keeping with our philosophy that the future of these two retail business corridors was everyone's business and responsibility, not just the responsibility of those who currently lived or owned businesses or residences on these streets. Both the public meetings and studio (class) presentations were held to openly discuss the current and future attributes of the Harrison Street and Oak Park AvenueEisenhower Districts. Each of them is briefly described in the project's timeline (see Appendix).

The large format public meetings were structured in a variety of ways to provide the appropriate level of feedback for the particular stage of the project. The earliest meetings were designed as information-gathering sessions for the UIC planning team and served as a means to establish a rapport in building a partnership between the planning team and the residents. Later public meetings were more specific in nature with the agendas derived from the progress made since the previous meeting. As the original designs became more defined, the original degree of participation was intentionally reduced to avoid revisiting low-level concerns previously resolved.

After several months of work, preliminary proposals were presented for review and comment at large public meeting that was promoted as a charrette. ${ }^{1}$ This event (held April 3, 2003) provided the general public with a hands-on opportunity to reshape TWO (high and low

\footnotetext{
${ }^{1}$ The French word "charrette" means "little cart" and is used to describe the final intense work effort expended by art and architecture students to meet a project deadline. Retrieved March 1, 2006, from http://oakparkinfo.lib. uic.edu/faq.htm.
} 
end options) design proposal which were carefully culled from eighteen concepts developed in the studio course the during phase I of the project. Due to heavy promotion and substantial content, more than 200 residents attended this meeting, a significant feat in Oak Park because of the large number of public meetings on any given day.

\section{Studio open houses}

Urban planning and design, especially when it involves the physical redevelopment of a neighborhood, is often a mysterious process to residents and ordinary citizens. What they often see is the finished product - a report, a plan, a drawing, a perspective rendering. Often these plans or drawings are presented as expert-driven solutions that have emerged from a rational planning processes supported by evidence and analysis. However, the reality of planning is that it is messy, iterative, and often influenced by values and desires that may conflict with hard evidence.

At the start of this project, the village provided UIC with a physical space (a studio on the street) where the planning classes could meet as well as open houses could be held. The space was critical to the development of our model of participatory planning process. It allowed us to open up the planning process to the community. In the initial stages, anyone who wandered into the studio was able to get a sense of how the students were developing their ideas and solutions to address perceived needs of each of the corridors. In fact, a few citizens attended specific classes in order to more fully understand the direction of the student's work.

The studio's opening hours were posted on the door. During the Fall, there were focused presentations on a particular topic-e.g., presentation of existing design conditions. During the Spring, the faculty staffed the studio and were available to discuss any aspect of the project with any stakeholder. A computer with a high-speed Internet connection was provided at the studio site so that personalized guidance and training was available as new IT tools were introduced. Having a local space to work enabled the UIC Team to better understand the competing needs of each stakeholder, thus the final product was directly influenced by a compromise derived from these meetings.

\section{One-on-one conversations}

Along the way, UIC team members initiated several one-on-one conversations about substantial issues concerning the project with many individuals. Some of these individuals eventually became part of the stakeholder process because of our discussions. Others opened their doors to offer us space to hold meetings and helped us in other ways. We used our professional and personal networks to support the idea of planning as a civic project, rather than a political one. These conversations were informal but were conducted on the phone, by email, in person. At each of our public meetings, we spent time before and after the presentation lingering to be available to residents who wished to discuss a specific issue with us, such as parking. 


\section{Nurturing a community of identity—the stakeholder group}

Oak Parkers are familiar with a sense of geographic community in that they live in an urban village - accessible to many amenities and offering an excellent quality of life for its residents. Through this project, we attempted to create a community of identity, a diverse group of residents who would come together to create and help to sustain the development of these two retail business districts. To this end, we began to invite participants to apply to become part of our stakeholder group. Earlier we reported over 75 five applicants for the stakeholder group. Although we were very clear about the work that was involved - they volunteered their time and energies to support the process because they cared about the well being of the community now and into the future.

The village has a strong history of grass-roots participation dating back 100 years. Aside from being known as the boyhood home of Ernest Hemingway and the home of Frank Lloyd Wright, Oak Park is also well known for its ground-breaking role in stopping the "White flight" during the late 1960s and early 1970s that plagued the City of Chicago. Oak Park was committed "to develop an autonomous, reform style of government and diversified bases of influence and prestige" (Goodwin, 1979). This reform style of government included an abundance of community involvement including planning. Oak Parkers pride themselves as a model community. This pride is reflected not only in the history, but the development of the government. An open planning process is a necessary step to continue this tradition. ${ }^{2}$

\section{Conclusions}

This project demonstrates the role of a librarian as scholar. By participating in the field work, development of the project, and participating in every aspect of the design, the authors were able to effectively monitor the information life cycle. While this examination focused specifically on how planners effect the information life cycle, one may adapt the unique contributions of this project to other social sciences. Specifically, the authors found

- the use of different computer-mediated communication and visualization techniques helped facilitate specific urban design and planning activities at the micro-neighborhood scale;

- the emphasis and attention placed on a participatory process was infused at different stages with innovative electronic technologies which enabled better access to information;

- the creation of a stakeholder group allowed for community memory to foster and develop; and

\footnotetext{
${ }^{2}$ There are a plethora of articles and chapters about Oak Park's history, but a good overall summary may be found at the Oak Park Public Library's web site. Retrieved March 1, 2006, from http://www.oppl.org/reference/ oakparkhistory.htm.
} 
- the introduction of fundamental library organization tools at the outset of the project allowed for more transparency in communication with the citizenry which addressed a key concern regarding an open planning process.

Digital technologies reinvigorated an already engaged community by creating proactive rather than reactive participatory planning processes. In addition, some of the techniques that were used to revitalize the participatory process were made possible because of the team's decision to use computer-mediated communication and visualization technologies. For instance, the use of a safe/neutral electronic space (the project Web site) allowed citizens to post anonymous comments and made it possible for citizens to share their real thoughts with the UIC team and the village officials. Likewise, the team was able to post documents and plans (work in progress) on the project Web site to show how ideas about the planning and design of the retail business districts evolved over time. In some instances, the technology was invisible to the end user. For example, the team used GIS as a back-end data processing and analysis tool. Traditional GIS-generated artifacts such as high-quality maps, and analyses of cadastre data were integrated into easy-to-use document formats such as PDF files and PowerPoint. Overall, the project demonstrates how computer-mediated communication and visualization technologies can be used to enhance traditional participatory planning. It requires extra time and a lot of patience, but an engaged citizenry aids the planning process.

Having a trained government information professional on the team made the transition from traditional planning to open participation more transparent. Knowledge of e-government precepts gave the project librarian the ability to keep both the government and the citizen focused on the process, rather than get bogged down in minutia. Few citizens participate in government and rare is the government that provides open and equal access to all its citizens. Information technologies enhanced the village's ability to inform their citizens and in turn received better feedback from the stakeholders. The success of this project is reflected by the village's adoption of the process developed by UIC for use in other village-sponsored planning projects.

The issues of information access would never be raised in a traditional planning project even though professional planners report the difficulty in obtaining local information (Ramasubramanian \& Quinn, 2006). While the planner depends on current information, having a librarian on the project brought the question of information accessibility to the forefront. As a result, the majority of the project faculty reported they gathered information differently than in other work. The citizens, on the other hand, reported an expectation that the village would house all the information and make it available whenever requested for free. Many felt they paid for the information with their time and their tax dollars while the village officials believed that the information created from this project was the property of the village, not necessarily the property of the citizens. Opening the planning process through the use of IT gave both the citizens and the village satisfaction that each had the relevant information they needed to proceed to implementation of the project recommendations. Introducing all parties to traditional library dissemination practices and maintaining open communication throughout the project enabled all the stakeholders to 
participate more fully than the traditional planning process. This project proves John Locke's theory that government should be from the people and that the people have a right to participate in their own government. By making access to information a central precept of the project, the authors created a transparent open planning process that meets the information needs of all constituents.

\section{Appendix A. Project timeline}

Phase 1: 8/22-02-12/5/02; Phase 2: 12/6/02-4/10/03; Phase 3: 4/11/03-8/23/03

\begin{tabular}{|c|c|c|}
\hline Activity & Start & Anticipated completion \\
\hline Kick-off meeting & $8 / 22 / 02$ & $8 / 22 / 02$ \\
\hline Fall semester starts & $8 / 26 / 02$ & $12 / 6 / 02$ \\
\hline Begin collecting data-existing conditions & $8 / 28 / 02$ & $10 / 9 / 02$ \\
\hline Meet with VOP & $8 / 28 / 02$ & On-going \\
\hline Studio space & $8 / 26 / 02$ & $6 / 30 / 03$ \\
\hline Take panoramic photos of existing corridors & & $9 / 18 / 02$ \\
\hline Construct intranet & $8 / 22 / 02$ & $9 / 1 / 02$ \\
\hline Construct public Web site & $8 / 22 / 02$ & $9 / 18 / 02$ \\
\hline First community meeting & $9 / 11 / 02$ & $9 / 18 / 02$ \\
\hline Draft work plan & $9 / 18 / 02$ & $10 / 4 / 02$ \\
\hline Traffic data & & $9 / 25 / 02$ \\
\hline Open lecture on IT & & $10 / 1 / 02$ \\
\hline Complete digital photos & $9 / 1 / 02$ & $10 / 8 / 02$ \\
\hline Open lecture on IT & & $10 / 8 / 02$ \\
\hline Final presentation of existing conditions & & $10 / 9 / 02$ \\
\hline Presentation of draft designs & & $10 / 30 / 02$ \\
\hline Demonstration of tools prototypes & & $10 / 31 / 02$ \\
\hline Develop vision statements & $9 / 18 / 02$ & $11 / 5 / 02$ \\
\hline Second community meeting - vision statements & $9 / 18 / 02$ & $11 / 5 / 02$ \\
\hline Show interactive tools & & $11 / 21 / 02$ \\
\hline Final presentation—designs & & $12 / 4 / 02$ \\
\hline Final presentation-IT tools & & $12 / 5 / 02$ \\
\hline Shopping survey & $12 / 6 / 03$ & $2 / 30 / 02$ \\
\hline Form core stakeholder group & $12 / 6 / 02$ & $3 / 15 / 03$ \\
\hline Third public meeting - goals and objectives & $12 / 6 / 03$ & $1 / 29 / 03$ \\
\hline Market report & $12 / 6 / 02$ & $1 / 30 / 03$ \\
\hline Parking analysis report & $1 / 1 / 03$ & $2 / 28 / 03$ \\
\hline Auto traffic analysis report & $1 / 1 / 03$ & $2 / 28 / 03$ \\
\hline Transit traffic analysis report & $1 / 1 / 03$ & $2 / 28 / 03$ \\
\hline Pedestrian traffic analysis report & $1 / 1 / 03$ & $2 / 28 / 03$ \\
\hline TDM analysis report & $1 / 1 / 03$ & $2 / 28 / 03$ \\
\hline Spring semester starts & $1 / 13 / 03$ & $5 / 9 / 03$ \\
\hline Refine urban designs & $1 / 13 / 03$ & $4 / 3 / 03$ \\
\hline Laxmi and Aimee complete IRB submission & $1 / 15 / 03$ & $3 / 26 / 03$ \\
\hline Develop best practices survey & $1 / 15 / 03$ & $4 / 3 / 03$ \\
\hline
\end{tabular}


Appendix A (continued)

\begin{tabular}{lll}
\hline Activity & Start & Anticipated completion \\
\hline Form stakeholder lists & $1 / 15 / 03$ & $3 / 12 / 03$ \\
Develop existing conditions survey & $1 / 15 / 03$ & $4 / 3 / 03$ \\
Fourth public meeting—charrette & $1 / 15 / 03$ & $4 / 3 / 03$ \\
Develop school project & $1 / 15 / 03$ & $5 / 7 / 03$ \\
Stakeholder retreat & $4 / 5 / 03$ & $4 / 6 / 03$ \\
Meet village manger about final draft & $4 / 11 / 03$ & $6 / 15 / 03$ \\
Team review of document & $4 / 17 / 03$ & $6 / 18 / 03$ \\
Character plan draft & $4 / 18 / 03$ & $6 / 5 / 03$ \\
Present draft to VOP team and stakeholders & & $6 / 5 / 03$ \\
Fifth public meeting—school charrette & $4 / 11 / 03$ & $4 / 25 / 03$ \\
Review and revise character plan & $6 / 19 / 03$ & $6 / 30 / 03$ \\
Complete draft report & $4 / 11 / 03$ & $6 / 30 / 03$ \\
Editorial time & $7 / 1 / 03$ & $7 / 30 / 03$ \\
Production of final products and report & $8 / 1 / 03$ & $8 / 23 / 03$ \\
Submit final products and report to VOP board & $8 / 23 / 02$ & $8 / 23 / 03$ \\
\hline
\end{tabular}

\section{References}

Alexander, Ernest R. (1992). Approaches to planning: Introducing current planning theories, concepts, and issues, 2nd ed. Philadelphia: Gordon and Breach Science Publishers.

Carp, Jana. (2004). Wit, style, and substance: How planners shape public participation. Journal of Planning Education and Research, 23(3), 242-254.

Chodorow, Stanley. (1996). Once there was a library here... The history of the University Library in the 21 st century. In Carol Hughes (Ed.), Scholarship in the new information environment: Proceedings from an RLG symposium (pp. 1-8). Mountain View, CA: Research Libraries Group.

E-Government Act of 2002, Pub. L. No. 107-347, 116 Stat. 2899, 2902 (December 17, 2002).

Friedmann, John. (1987). Planning in the public domain: From knowledge to action. Princeton: Princeton University Press.

Goodwin, Carole. (1979). The Oak Park Strategy: Community control of racial change. Chicago: University of Chicago Press.

For a fuller explanation of these methods, please see Hoch, Charles, et al. (2003). Planning together: Character plans for Oak Park Commercial Districts. Retrieved July 20, 2006, from http://www.uic.edu/cuppa/udv/ open me.htm

E-mail management software developed by Michael McClennan at the University of Michigan for the Internet Public Library. In collaboration, UIC used this software for managing electronic mail related to the UIC Oak Park Project. For more information about this software, please see Lagace, Nettie, and McClennan, Michael. (1998). QRC: We call it quirk. Computers in Libraries, 18(2), 26-27.

Locke, John. (1980). Of the state of nature, of civil government taken from two treatises of government. In Charles Hirschfeld (Ed.), Classics of Western Thought, The Modern World, 3rd ed. New York: Harcourt Brace Jovanovich.

Taken from the Arlington County: A leader in technology-based economic development by Heike Mayer. Retrieved March 1, 2006, from http://www.ostina.org/html/bridges/printer_friendly.htm?show=individualArticle\&article= 1314; and The impact of mobile communication on land use planning by Juha Talvitie. Retrieved March 1, 2006, from http://www.fig.net/pub/fig_2003/TS_10/TS10_4_Talvitie.pdf 
For an overview of the profession of Urban Planning, please see Myers, Dowell and Banerjee, Tridib. (2005). Toward greater heights for planning: Reconciling the difference between profession, practice, and academic field. Journal of the American Planning Association, 71(2), 121-129.

Putnam, Robert D. (2000). Bowling alone: The collapse and revival of American Community. New York: Simon and Schuster.

Ramasubramanian, L., \& Quinn, A. C. (2006). Visualizing alternative urban futures: using spatial multimedia to enhance community participation and policymaking. In Campagna, Michele (Ed.), GIS for sustainable development (pp. 467-486). Boca Raton: Taylor \& Francis: CRC Press.

Shiode, Narushige. (2000). Urban planning, information technology and cyberspace. Journal of Urban Technology, $7(2), 105-126$.

Smith, J. T. (1996). Meta-analysis: The librarian as a member of an interdisciplinary research team. Library Trends, 45(2), 265-279.

Village of Oak Park. (1990, September). 1990 Oak Park Comprehensive Plan (Chap. 1). Retrieved March 1, 2005, from VOP Web site http://www.oak-park.us/public/pdfs/Downtown\%20Plan/1990\%20Comprehensive\% 20Plan.pdf

Aimée A. Quinn serves as the review editor for Government Information Quarterly. She is an assistant documents librarian and assistant professor at the University of Illinois at Chicago. She earned her MLIS degree from Louisiana State University and BFA from the University of New Mexico. She has published articles on the preservation of the Serial Set, rare and valuable government publications and electronic government information. Her current research is on the impact of information technologies on government information and civic engagement. She currently serves as the Chair-Elect of the Government Documents Round Table of the American Library Association.

Laxmi Ramasubramanian is an architect (B.Arch and M.Arch from the University of Madras, India), and a city planner (MCP from the Massachusetts Institute of Technology). She seeks to inform and transform urban design policy and its practice in order to create a just and equitable society. Her research investigates the theory and practice of participatory planning; specifically the role that digital technologies (e.g., GIS, multimedia, urban simulations) play in fostering civic engagement and participatory democracy. She also has a substantive research interest in understanding young people's socio-spatial behavior in order to create inclusive public spaces and places. After receiving her PhD in 1998, Laxmi lived and worked in Australia and New Zealand. From 2002-2004, she served as Research Assistant Professor and Associate Director of the Urban Data Visualization Lab at the University of Illinois at Chicago (UIC). 